Ks. Jacek Goleń

Verbum Vitae 28 (2015) 423-458

\title{
ROLA ŚWIADECTWA W RODZINIE
}

\section{The Role of Testimony in the Family}

Abstract: True humanness reaches its fulfillment in Christ. It is faith that enables one to appreciate fully that gift of humanness, its value and its meaning, as well as to realize the marital-familial vocation. Testimony given to Christ in the Christian family takes on a more visible form as it harmonizes with the mature testimony of humanness. An important role of testimony in the family expresses itself in the objectives of this testimony. The testimony of humanness expresses itself in the task of building a community of persons and lasting marriage, respect towards persons and the human body, and commitment to maturing love and the realization of parenthood. Testimony of faith is connected with the task of professing God's Word, realization of one's baptismal priesthood, love and apostolate. Sacramental grace and prayer enable spouses and other family members to fully discover and realize these tasks.

Key words: testimony, humanity, humanness, faith, marriage, family, domestic Church.

Streszczenie: Człowieczeństwo osiąga swoją pełnię w Chrystusie. Wiara pozwala pełniej odkrywać dar człowieczeństwa, jego wartość i znaczenie oraz pełniej realizować powołanie małżeńsko-rodzinne. Świadectwo dawane Chrystusowi w rodzinie chrześcijańskiej przybiera czytelną formę wtedy, gdy harmonizuje z dojrzałym świadectwem człowieczeństwa. Doniosła rola świadectwa w rodzinie wyraża się w zadaniach, jakie ono spełnia. Świadectwo człowieczeństwa wyraża się w zadaniu budo- 
wania komunii osób i trwałego małżeństwa, szacunku dla osoby i ludzkiego ciała, zaangażowaniu w dojrzewanie miłości oraz realizacji rodzicielstwa. Świadectwo wiary łączy się z zadaniem głoszenia słowa Bożego, spełniania kapłaństwa chrzcielnego oraz miłości służebnej i apostolatu. Do pełniejszego odczytania i realizacji tych zadań uzdalnia małżonków i członków rodziny łaska sakramentalna i modlitwa.

Słowa kluczowe: świadectwo, człowieczeństwo, wiara, małżeństwo, rodzina, domowy Kościół

Świadectwo w swej najgłębszej istocie jest „odsłonięciem się osoby przed osobą"1. Świadectwo chrześcijańskie jest odsłonięciem się jednocześnie w wymiarze ludzkim i w wymiarze wiary. Podobną myśl podsunął Sobór Watykański II, stwierdzając, że w rodzinie chrześcijańskiej dzieci doświadczają zdrowej społeczności ludzkiej i Kościoła, do którego są wprowadzane (por. DWCh 3). Papież Benedykt XVI podkreślił nierozdzielny związek kształtowania osoby i przekazu wiary w wychowaniu, przy czym zaznaczył, że przekaz ten zwieńcza kształtowanie osoby $\mathrm{i}$ jest jego celem ${ }^{2}$.

Świadectwo chrześcijańskie w rodzinie bazuje na stwórczym i zbawczym obdarowaniu człowieka ${ }^{3}$, a rodzina dzięki temu stanowi „ludzką przestrzeń” spotkania z Chrystusem ${ }^{4}$. List do rodzin podkreśla, że ponieważ Chrystus narodził się i wzrastał w rodzinie, tajemnica wcielenia Słowa pozostaje w ścisłym związku z każdą rodziną. Sam Chrystus w rodzinie i przez rodzinę, ,objawia w pełni człowieka samemu człowiekowi"'s. Zatem, zarówno człowieczeństwo, jak też życie małżeńskie i rodzinne osiągają swoją pełnię poprzez wiarę w Chrystusa. Jednocześnie niedobory na poziomie ludzkim, ujawniające się w życiu małżeńsko-rodzinnym, osłabiają albo fałszują świadectwo wiary.

\footnotetext{
1 Mastej, „Świadectwo”, 239.

2 Por. Benedykt XVI, „Rodzina chrześcijańska”.

3 Por. Benedykt XVI, ,Rodzina chrześcijańska”.

4 Benedykt XVI, „Ewangelizacja i rodzina”.

5 Jan Paweł II, List do rodzin, 2 [dalej: LdR].
} 


\section{DośWIAdCZenie Źródeem ŚWIADECTWa}

Dawanie świadectwa jest naturalną konsekwencją osobistego doświadczenia. Świadectwo implikuje dwa następujące po sobie etapy: bycie świadkiem czegoś oraz danie świadectwa. Trzeba najpierw czegoś doświadczyć, aby następnie móc zaświadczyć lub poświadczyć ${ }^{6}$. Świadectwo chrześcijańskie $w$ rodzinie domaga się zatem najpierw doświadczenia człowieczeństwa. Jego podstawą jest odkrycie stwórczego obdarowania. Człowiek odkrywa w sobie wpisane w człowieczeństwo prawa natury, potrzeby i dążenia, wynikające ze stworzenia mężczyzny i kobiety na obraz i podobieństwo Boże (por. Rdz 1,2728). Jednym $z$ tych dążeń jest wpisane w serce człowieka uzdolnienie do miłości. Według papieża Benedykta XVI relacja między mężczyzną i kobietą jest zakorzeniona w najgłębszej istocie człowieka, a realizacja powołania do miłości upodabnia człowieka do Boga ${ }^{7}$. Plan Boży wpisany w serce mężczyzny i kobiety sprawia, że ,ich wzajemna miłość staje się obrazem absolutnej i niezniszczalnej miłości, jaką Bóg miłuje człowieka"8. Doświadczenie Bożego zamysłu wobec małżeństwa łączy się ściśle z odkryciem znaczenia jego nierozerwalności. Miłość między osobami domaga się instytucji małżeństwa, która ustanawia przestrzeń odpowiedzialności i wierności oraz gwarantuje trwałość wspólnoty. Instytucja małżeństwa jest „potrzebą wpisaną w samą naturę małżeńskiego przymierza miłości i w głębię osobowości człowieka". Ponadto Bóg jako twórca małżeństwa (por. KDK 48), wpisał w męskość i kobiecość spójne $\mathrm{z}$ dążeniem do daru z siebie dążenie

${ }^{6}$ Por. Jaworski, „Prorok jako świadek”, 78.

${ }^{7}$ Benedykt XVI, „Rodzina chrześcijańska”.

${ }^{8}$ Katechizm Kościoła Katolickiego, 1604 [dalej: KKK].

${ }^{9}$ Benedykt XVI, „Rodzina chrześcijańska”. Synod Biskupów (2015) podkreślił, że nierozerwalność odpowiada głębokiemu pragnieniu wzajemnej i trwałej miłości, jakie Stwórca umieścił w sercu człowieka i jest Jego darem dla każdego małżeństwa. Zob. Relazione Finale del Sinodo dei Vescovi al Santo Padre Francesco (24.10.2015), 48 [dalej: RF]. 
do przekazywania życia ${ }^{10}$. Zatem w ludzkiej płciowości zespolonej z osobą i ukierunkowanej na dar z siebie w miłości i przekazywanie życia, jak również w wewnętrznej potrzebie instytucji małżeństwa, mężczyzna i kobieta doświadczają obecności Boga i Jego miłości oraz rozpoznają swoje podstawowe powołanie.

Odkrywanie swego człowieczeństwa oraz jego celów i dyspozycji dokonuje się nie tylko poprzez fakt własnej egzystencji, zdobycie pewnej wiedzy o człowieku i oddziaływania kulturowe. Istotne znaczenie ma spotkanie z dojrzałym człowieczeństwem rodziców lub innych osób znaczących, polegające na pozytywnym wsparciu miłością i przykładem, które papież Jan Paweł II nazwał obdarowaniem człowieczeństwem ${ }^{11}$. Spotkanie to pomaga w rozwoju osobowym świadka. Sprzyja kształtowaniu jego tożsamości oraz osiąganiu dojrzałości psychicznej, społecznej, moralnej i religijnej.

U podstaw wiarygodnego świadectwa chrześcijańskiego musi leżeć doświadczenie osobistej, nadprzyrodzonej więzi z Chrystusem oraz zaangażowanie w tę relację. Świadek pozostający w Chrystusem w osobowym związku wyraża go poprzez ewangeliczny styl życia ${ }^{12}$. Papież Benedykt XVI stwierdził, że w wychowaniu do wiary główną rolę odgrywa świadek, który nie wskazuje na siebie samego, ale na Chrystusa - wielkiego Świadka Ojca (por. J, 8,28), którego spotkał i którego niezawodnej dobroci doświadczył. ,Staje się on punktem odniesienia w takiej mierze, w jakiej potrafi uzasadnić nadzieję, która go podtrzymuje w życiu (por. 1 P 3,15), i w jakiej sam żyje prawdą, którą głosi" ${ }^{13}$. Doświadczenie działania Boga leżące u podstaw świadectwa wiary dokonuje się głównie za pośrednictwem Kościoła, który rodzi, wychowuje i buduje rodzinę chrześcijańską. Kościół, głosząc słowo

${ }^{10}$ Kongregacja Wychowania Katolickiego, Wytyczne wychowawcze, 32 [dalej: WW].

${ }^{11}$ Por. LdR 16.

12 Por. Mastej, „Świadectwo”, 240.

${ }^{13}$ Benedykt XVI, „Rodzina chrześcijańska”. 
Boże, objawia rodzinie jej tożsamość; sprawując sakramenty, wzbogaca i umacnia ją łaską Chrystusa, a poprzez głoszenie przykazania miłości pobudza i prowadzi ją do naśladowania tej samej miłości oddania i ofiary, którą Chrystus żywi do ludzkości ${ }^{14}$. Doświadczenie to wspiera i pogłębia modlitwa osobista i wspólnotowa.

Doświadczenie nadprzyrodzonej więzi z Chrystusem pozwala rozpoznawać - dzięki łasce Bożej - głębię oraz nadprzyrodzony sens stwórczego i zbawczego obdarowania. Bóg już w sakramencie chrztu czyni wierzących swoimi świadkami, a następnie umacnia ich w sakramentach bierzmowania i Eucharystii do dawania świadectwa chrześcijańskiego. Specyficzne ubogacenie i umocnienie dokonuje się w sakramencie małżeństwa, który zawierają ochrzczeni ${ }^{15}$. Ich wiara wsparta sakramentami pozwala rozpoznać w nierozerwalnej więzi małżonków odblask miłości Trójcy Świętej ${ }^{16}$. Papież Franciszek dodaje, że szaleństwo bezinteresowności miłości małżeńskiej wyłącznej i ,aż do śmierci” staje się zrozumiałe tylko w świetle szaleństwa paschalnej miłości Jezusa ${ }^{17}$. Naturalna miłość małżeńska w sakramencie małżeństwa zostaje przez Chrystusa darem Jego łaski uzdrowiona, udoskonalona i wywyższona ${ }^{18}$ tak, że osiąga poziom nadprzyrodzonej komunii - bycia jednym ciałem, na wzór zjednoczenia Chrystusa z Kościołem (por. Ef 5,31-32). Sakrament ten pozwala małżonkom tworzyć głęboką wspólnotę życia i miłości - „najściślejsze zespolenie osób i działań” (KDK 48), a jednocześnie uzdalnia ich do wypełnienia powołania małżeńskiego i rodzicielskiego. Chrześcijańscy małżonko-

${ }^{14}$ Jan Paweł II, Familiaris consortio, 49 [dalej: FC].

${ }^{15}$ Por. Kodeks Prawa Kanonicznego, kan. 1055 § [dalej: KPK]; FC 49; RF 36.

${ }^{16}$ Por. RF 36.

${ }^{17}$ Franciszek, Od początku stworzenia Bóg błogosławi ludzką miłość. Homilia podczas Mszy św. na rozpoczęcie Synodu (4.10.2015); por. RF 1.

${ }^{18}$ FC 56. 
wie otrzymują łaskę bycia wzajemnie dla siebie, dla swoich dzieci oraz domowników świadkami wiary (DA 11) ${ }^{19}$.

Analogicznie do dwojakiego rodzaju doświadczenia działania Boga i Jego obdarowania można mówić o dwojakiej roli świadectwa małżonków i członków rodziny o roli świadectwa człowieczeństwa oraz świadectwa wiary.

\section{Rola ŚWIADECTWA CZLOWIECZEŃSTWA}

Świadectwo, dzięki odsłonięciu się osoby, pozwala wejść w jej świat i doświadczyć jej w międzyosobowej relacji ${ }^{20}$. W relacjach małżeńskich i rodzinnych człowiek odsłania się najpierw jako kobieta lub mężczyzna, żona lub mąż, matka lub ojciec. Synod Biskupów (2015) podkreśla, że warto spojrzeć w kluczu chrystologicznym na naturalne właściwości małżeństwa stanowiące dobro małżonków (jedność, otwartość na życie, wierność i nierozerwalność $)^{21}$. Odsłanianie się małżonków w wymiarze naturalnym stanowi podstawowy sposób dawania świadectwa o Bożym zamyśle dotyczącym małżeństwa i rodziny wpisanym w człowieczeństwo. Dobre świadectwo w tym wymiarze wyraża się w dojrzałości ludzkiej kobiety i mężczyzny, szacunku i miłości wobec współmałżonka, życiu w trwałym i instytucjonalnym małżeństwie, realizacji zobowiązań przysięgi małżeńskiej, a także szacunku wobec ludzkiej płodności i daru życia oraz odpowiedzialnym rodzicielstwie ${ }^{22}$. Dobre świadectwo rodziców jako wychowawców obejmuje nie tylko tworzenie trwałego i stabilnego małżeństwa, ale także zapewnienie dzieciom obecności, pozytywnych wzorców wychowawczych matki

${ }^{19}$ W RF 7 czytamy, że tożsamość chrześcijańska i kościelna rozkwita w pięknie życia rodzinnego.

${ }^{20}$ Por. Mastej, „Świadectwo”, 239.

${ }^{21}$ RF 47.

${ }^{22}$ Zob. Paweł VI, Humanae vitae, 10 [dalej: HV]. 
i ojca, tworzenie klimatu miłości w rodzinie oraz stopniowe „rodzenie” w procesie wychowania ${ }^{23}$.

\section{1. Świadectwo komunii osób i trwałego malżeństwa}

Dla zrozumienia świadectwa człowieczeństwa dawanego przez mężczyznę i kobietę w małżeństwie i rodzinie kluczowe wydaje się odwołanie się do pierwotnego doświadczenia ich jedności. Bóg bowiem stworzył ich dwoistość w oparciu o ich substancjalną jedność. Dlatego świadectwo męskości i kobiecości oraz wzajemnej jedności pozwala mężczyźnie i kobiecie poznawać siebie samych.

W pierwotnym doświadczeniu oboje odkryli, że kobieta dla mężczyzny i mężczyzna dla kobiety stanowią ,pomoc w zaistnieniu, w pełnym odnalezieniu siebie samego lub siebie samej" ${ }^{24}$, pomoc w byciu człowiekiem ${ }^{25}$. Papież Benedykt XVI stwierdził, że mężczyzna i kobieta jedynie razem przedstawiają całokształt człowieczeństwa ${ }^{26}$, a Franciszek przypomniał, że mężczyzna i kobieta jako para są obrazem Boga ${ }^{27}$. Dlatego aż po dzień dzisiejszy odkrywają oni, że oboje konstytuują siebie nawzajem i nie mogą istnieć niezależnie od siebie, a ich bezpośrednie spotkanie staje się spełnieniem ${ }^{28}$. Różnica płci mężczyzny i kobiety nie stanowi przypadłościowego aspektu drugiej osoby, który można sobie przywłaszczyć, ale jest jej elementem konstytutywnym. Różnicy tej nie jest w stanie ująć i oddać zwykła komplementarność. Męskość i kobiecość są bowiem cielesnym przejawem wspólnego im obojgu człowieczeństwa, które jest dwoiste i rozpoznaje siebie dopiero

${ }^{23}$ Por. LdR 16; zob. Papieska Rada do spraw Rodziny, Ludzka ptciowość, 48-55 [dalej skrót: LP].

${ }^{24}$ McCarthy, „Miłość oblubieńcza”, 142-144.

${ }^{25}$ Jan Paweł II, Mulieris dignitatem, 7 [dalej: MD].

${ }^{26}$ Benedykt XVI, Deus caritas est, 11 [dalej: DCE].

${ }^{27}$ Franciszek, ,Kreatywność i śmiałość”.

${ }^{28}$ McCarthy, „Miłość oblubieńcza”, 143. 
w odniesieniu do drugiej osoby ${ }^{29}$. Synod Biskupów (2015) podkreślił, że bez wzajemnego ubogacania się oboje nie mogą w pełni zrozumieć, co to znaczy być mężczyzną i kobietą ${ }^{30}$.

W tym rozpoznawaniu siebie i odkrywaniu własnej tożsamości w relacji z drugą osobą kluczowym warunkiem jest tworzenie komunii osób. Nieusuwalne wezwanie do tej komunii zostało wpisane przez Stwórcę w serce mężczyzny i kobiety i jest znakiem ich osobowej natury ${ }^{31}$. Dlatego odnajdywanie siebie i swojej jedyności wraz z drugą osobą i w niej dokonuje się najpełniej poprzez wzajemne obdarowanie, wyrażające się w trwałym zjednoczeniu byciu ,jednym ciałem" - małżeństwa nierozerwalnego ${ }^{32}$. Inaczej bowiem jak tylko przez bezinteresowny dar z siebie samego człowiek nie może odnaleźć się w pełni (por. KDK 24). Zatem dopiero miłość oblubieńcza, rozumiana jako dar $z$ siebie, realizowana w trwałej komunii małżeńskiej i rodzinnej oraz w trwałym małżeństwie, pozwala małżonkom wzajemnie odnajdywać siebie w pełni jako mężczyzna i kobieta. Wówczas mogą oni odnajdywać oblubieńcze znaczenie ciała, gdy dar z ciała wyraża dar z siebie składany jednej osobie przez drugą w sposób nieodwracalny, w wymiarze całego życia ${ }^{33}$. Poprzez to najściślejsze zespolenie osób i działań doświadczają sensu swej jedności (KDK 48). W tym kontekście wydaje się, że sensu i znaczenia kobiecości i męskości oraz małżeństwa, nie sposób zrozumieć w pełni bez świadectwa objawienia chrześcijańskiego. Świadectwo przeżywania seksualności w sposób autentycznie ludzki - podporządkowany dynamice wzajemnego daru i komunii osób - jest możliwe w pełni w małżeństwie sakramentalnym, z pomocą łaski tego sakramentu ${ }^{34}$.

${ }^{29}$ McCarthy, „Miłość oblubieńcza”, 144.

${ }^{30} \mathrm{RF} 8$.

${ }^{31}$ Semen, Seksualność, 29.

${ }^{32}$ Por. McCarthy, „Miłość oblubieńcza”, 144-145.

${ }^{33}$ Merecki, „Ciało”, 179.

${ }^{34}$ Por. Semen, Seksualność, 14, 144. 
W świetle nauczania soborowego $\mathrm{w}$ małżeństwie mężczyzny i kobiety ujawnia się wrodzona godność oraz niezwykła wartość sakralna. Komunia osób będąca wzajemnym oddaniem się sobie mężczyzny i kobiety oraz dobro dzieci wymagają pełnej wierności małżonków i nieprzerwalnej jedności ich współżycia (por. KDK 47, 48). Świadectwo nierozerwalnej komunii podkreśla wartość małżeństwa oraz ukazuje świętość węzła małżeńskiego. Dlatego stanowi ono obecnie najważniejszą część apostolstwa małżonków (por. DA 11; KDK 52).

Myśl tę rozwinął papież Jan Paweł II, stwierdzając, że „dawanie świadectwa bezcennej wartości nierozerwalności i wierności małżeńskiej jest jednym z najcenniejszych i najpilniejszych zadań małżonków chrześcijańskich naszych czasów". Małżonkowie, którzy pomimo prób zachowują i rozwijają dobro nierozerwalności, wypełniają pokornie i odważnie zadanie bycia $\mathrm{w}$ świecie wyraźnym znakiem „niestrudzonej wierności, z którą Bóg i Jezus Chrystus miłują wszystkich ludzi i każdego człowieka"35. Papież Benedykt XVI dodał, że świadectwo wierności i nierozerwalności małżeństwa otwiera perspektywę dla autentycznego człowieczeństwa małżonków oraz pozwala dzieciom, będącym owocem miłości wierzyć w człowieka i w jego przyszłośćc ${ }^{36}$. Synod Biskupów (2015) sprecyzował, że świadectwo małżonków trwałe w czasie, dawane we wspólnocie chrześcijańskiej, pomaga młodzieży zyskiwać większe zaufanie do decyzji o małżeństwie ${ }^{37}$.

\section{2. Świadectwo szacunku dla osoby i ludzkiego ciala}

Stworzenie mężczyzny i kobiety przez Boga z miłości na obraz i podobieństwo Boże (Rdz 1,27-28) oraz powołanie ich do miłości wyznacza dalsze obszary świadectwa małżonków w wymiarze ludzkim. Według papieża Jana

\footnotetext{
${ }^{35}$ FC 20.

${ }^{36}$ Por. Benedykt XVI, „Rodzina chrześcijańska”.

${ }^{37}$ RF 29.
} 
Pawła II stworzenie oznacza podstawowe obdarowanie, a ludzkie ciało $\mathrm{z}$ jego męskością i kobiecością jest jego wyrazem. Ciało ludzkie jest prasakramentem, dotykalnym znakiem obecności Boga ${ }^{38}$. Wynikający ze stworzenia związek między Bogiem i człowiekiem powoduje nierozerwalną więź ludzkiego ducha i ciała. Człowiek jest duszą wyrażającą się w ciele i ciałem ożywianym przez nieśmiertelnego ducha ${ }^{39}$. Ciało mężczyzny lub kobiety zawiera pierwotny zamiar Boga - jest ciałem odkupionym i powołanym do zmartwychwstania ${ }^{40}$. Osoba ,odkrywa w sobie wezwanie do przyjęcia go i rozwijania zgodnie z owym pierwotnym projektem - wyrażonym w różnicy płci - wpisanym w nie od samego początku przez Stwórcę"41. Doświadczenie obdarowania człowieka ciałem oraz seksualnością zespolonymi z osobą pozwala mu dostrzegać w nich znak działania i dar samego Boga. Obdarowanie to domaga się przyjęcia i odpowiedzi na ten dar.

Pierwszą częścią tej odpowiedzi jest świadectwo zachowania czystości i wstrzemięźliwości seksualnej przez młodzież i narzeczonych ${ }^{42}$. Dalszą część tej odpowiedzi na obdarowanie ciałem i seksualnością stanowi świadectwo szacunku małżonków dla godności osoby i sumienia oraz przyjęcia daru męskości i kobiecości zgodnie z Bożym zamysłem. Wobec zachwiania spojrzenia na godność osoby oraz ludzkie ciało i seksualność, spowodowanego w człowieku przez grzech pierworodny, pomocą w odczytywaniu Bożego zamysłu wobec daru ludzkiej seksualności jest - także dla małżonków - czystość serca. Pozwala ona człowiekowi rozpoznać zasadnicze rysy ,początku” i przybliżać się do stanu pierwotnej niewinności, w którym powołaniem seksualności było wyrażanie komunii Osób Boskich $^{43}$.

\footnotetext{
38 Por. Merecki, „Ciało”, 183.

39 Benedykt XVI, „Rodzina chrześcijańska”; por. LdR 19.

40 Por. Semen, Seksualność, 48, 110.

41 Merecki, „Ciało”, 183.

42 Por. KKK 2349-2350.

43 Semen, Seksualność, 57, 109.
} 
Świadectwo czystej miłości narzeczeńskiej (por. KDK 49) i wstrzemięźliwości seksualnej, a następnie wyrastające z niego świadectwo czystości małżeńskiej (por. KDK 51) umacnia świadomość godności osoby i ludzkiego ciała oraz wartości darów seksualności i związanej z nią płodności. Jan Paweł II ukazał wielorakie owoce czystości narzeczeńskiej i małżeńskiej służące miłości, małżeństwu i rodzinie ${ }^{44}$. Wykazał także, iż ,akt małżeński, wyzuty ze swej wewnętrznej prawdy, pozbawiony sztucznie znaczenia potencjalnego rodzicielstwa, przestaje być również aktem miłości”"45. Podkreślił, że czystość małżeńska oraz służące jej opanowanie i okresowa wstrzemięźliwość sprzyja rozwojowi osobowościowemu i duchowemu małżonków, wprowadza w rodzinę harmonię i pokój, sprzyja trosce i budzi szacunek wobec współmałżonka, pomaga wyzbyć się egoizmu, wzmacnia poczucie odpowiedzialności oraz umożliwia głębszy i skuteczniejszy wpływ wychowawczy na potomstwo ${ }^{46}$. W celu praktycznej realizacji wymogów czystości małżeńskiej II Polski Synod Plenarny wezwał małżonków chrześcijańskich do dawania świadectwa wartości i znaczenia planowania poczęć opartego na znajomości biologicznego cyklu kobiety dla wiernej i szczęśliwej miłości małżeńskiej ${ }^{47}$. Świadectwo czystości narzeczeńskiej i małżeńskiej jest wyrazem szacunku dla godności osoby w jej duchowo-cielesnej jedności oraz dla ludzkiej seksualności i płodności.

\section{3. Świadectwo zaangażowania w dojrzewanie milości}

Świadectwo daru z siebie i komunii osób w małżeństwie oraz szacunku dla osoby i czystości łączą się ściśle z dojrzewaniem miłości i je zakładają. Sobór Watykański II

\footnotetext{
${ }^{44}$ Zob. Jan Paweł II, „Głoście światu”, 109-114.

45 Jan Paweł II, „Co jest prawdziwym dobrem człowieka?”, 6.

${ }^{46}$ FC 33; por. LP 20.

${ }^{47}$ Por. II Polski Synod Plenarny, ,Powołanie do życia w małżeństwie i rodzinie", 54.
} 
stwierdza, że miłość małżeńska udoskonala się i wzrasta przez swoje szlachetne działanie. Powinna ona zdecydowanie przewyższać czysto erotyczną skłonność, która jest nastawiona egoistycznie oraz szybko i żałośnie zanika (por. KDK 49). Miłość eros, która jest zapowiedzią szczytu istnienia i szczęśliwości, do której dąży człowiek, w pewien sposób narzuca się mężczyźnie i kobiecie. Nie pochodzi ona $\mathrm{z}$ ich myśli i woli, ale jest miłością ziemską, pożądliwą i posesywną. Dlatego nie powinna być ubóstwiana, gdyż wówczas może stać się nieludzka i prowadzić do używania osób i ich degradacji. Potrzebuje ona dojrzewania poprzez spotkanie z miłością agape, która odkrywa drugiego człowieka, troszczy się i służy, poszukuje dobra osoby ukochanej, a w imię tego jest gotowa do wyrzeczeń i poświęceń. Właśnie poprzez dyscyplinę i wyrzeczenia oraz oczyszczanie i uzdrawianie eros może osiągnąć swoją prawdziwą wielkośćc ${ }^{48}$. Człowiek bowiem staje się naprawdę sobą, gdy ciało i dusza odnajdują się w wewnętrznej jedności i gdy kocha on jako osoba. Prawdziwa natura miłości nie wyczerpuje się w erosie, ale ujawnia się ona wtedy, gdy eros i agape odnajdą właściwą jedność w niepowtarzalnej rzeczywistej miłości osób ${ }^{49}$. Zarówno dla lepszego rozumienia znaczenia miłości małżeńskiej, jak również ze względu na dostrzegany w społeczeństwach zachodnich kryzys więzi małżeńskich i rodzinnych warto docenić znaczenie świadectwa dojrzewania małżonków w miłości.

Proces dojrzewania miłości małżeńskiej odbywa się na kilku etapach. Pierwszym jest uwewnętrznienie miłości eros. Seksualna miłość afektywna i zmysłowa stopniowo uwalnia się od presji popędu i staje się coraz bardziej zależna od władz duchowych człowieka, czyli przeżywana w sposób świadomy i wolny. Ważne jest tutaj świadome

${ }^{48}$ Por. DCE 3-7.

${ }^{49}$ Miłość agape integruje wszystkie inne znaczenia miłości związane ze sferą cielesną i psychiczną, jak miłość upodobania, pożądania czy przyjaźni, czepiąc z nich dynamizm i ukierunkowanie. Zob. Wieczorek, „Życie duchowe małżeństwa i rodziny”, 107. 
podjęcie przez małżonków wysiłku dojrzewania w miłości. Drugim etapem jest oczyszczanie miłości eros z egoizmu ku pogłębieniu w niej postawy przyjaźni filia. Coraz głębsze postrzeganie miłości przez pryzmat oczekiwań i potrzeb współmałżonka pozwala przechodzić coraz bardziej od czułości i serdeczności o zabarwieniu egoistycznym do postawy bezinteresownego i bezwarunkowego daru z siebie. Na tym etapie pojawia się już gotowość poświęcenia siebie dla dobra żony czy męża. Trzeci etap wykracza już poza obręb naturalnych ludzkich skłonności. Nierzadko okazuje się, że siłą własnych naturalnych zdolności i motywacji człowiek nie jest w stanie uwolnić się od przywiązania do swoich cielesnych i psychicznych potrzeb. Wówczas w małżeństwie wyraźnie pojawia się potrzeba otwarcia miłości małżeńskiej na nadprzyrodzoną miłość agape, będącą darem Boga. Chodzi o otwarcie się i zjednoczenie małżeńskiego życia z życiem Boga. Wówczas miłość Boża stopniowo obejmuje władze poznawcze, wolitywne, sferę cielesną i emocjonalną i antycypuje życie wieczne z Bogiem ${ }^{50}$.

Tak więc eros podlega „humanizacji” - początkowo pożądający, w zbliżeniu do drugiej osoby będzie coraz bardziej szukał jej szczęścia, troszczył się o nią i pragnął być „dla niej”. Jeśli ten element miłości agape nie przemieni erosa, wówczas upada on i traci swoją naturę ${ }^{51}$. Sam eros zakorzeniony w naturze kieruje człowieka ku małżeństwu charakteryzującemu się wyłącznością i definitywnością ${ }^{52}$. Do rozwoju miłości należy bowiem to, że poszukuje ona definitywności w podwójnym znaczeniu: w sensie wyłączności - tylko jedna osoba, oraz w sensie „na zawsze" ${ }^{53}$. Trzeba zauważyć, że w rozwoju miłości pomocna jest wiara, gdyż miłość agape, która przemienia erosa, jest oparta na wierze i przez nią jest kształtowana ${ }^{54}$. Zatem ludzkie

${ }^{50}$ Wieczorek, „Życie duchowe małżeństwa i rodziny”, 109-110.

${ }^{51}$ Por. DCE 7.

${ }^{52}$ DCE 11.

${ }^{53}$ DCE 6.

${ }^{54}$ Por. DCE 7. 
dyspozycje i dążenia związane z miłością na poziomie naturalnym, dzięki odkryciu i przyjęciu Bożego zamysłu dotyczącego miłości, zyskują nową jakość i mogą zostać w pełni zrealizowane. Ludzka miłość niesie zatem z sobą zaproszenie do dojrzewania, aby mogła stawać się coraz bardziej czytelnym świadectwem człowieczeństwa.

Miłość nigdy nie jest „skończona” i spełniona, ale zmienia się i dojrzewa wraz z biegiem życia ${ }^{55}$. Zaangażowanie małżonków w dojrzewanie miłości - jej oczyszczanie, uzdrawianie i osiąganie prawdziwej jej wielkości - jest czytelnym świadectwem dawanym samemu sobie, współmałżonkowi, dzieciom oraz otoczeniu. Ponadto - jak stwierdził papież Benedykt XVI - wyjście naprzeciw bliźniemu i okazywanie mu miłości czyni człowieka wrażliwym również na Boga ${ }^{56}$. Zatem świadectwo doskonalenia miłości małżeńskiej nie tylko umacnia więź i wspólnotę małżeńską i rodzinną, ale może także prowadzić do wiary w Boga, który jest miłością (por. $1 \mathrm{~J}$ 4,8) i działa poprzez ludzką miłość. Ten związek zaangażowania w dojrzewanie miłości z wiarą jest godną podkreślenia cechą świadectwa i apostolstwa we współczesnej rzeczywistości. Zaangażowanie narzeczonych i małżonków w dojrzewanie miłości sprzyja bowiem mistagogicznemu odkrywaniu obecności Pana w celebracji ich przymierza oraz w historii ich wspólnej miłości ${ }^{57}$.

\section{4. Świadectwo rodzicielstwa}

Świadectwo w wymiarze ludzkim obejmuje także świadectwo rodzicielstwa. Papież Jan Paweł II stwierdził, że ludzkie rodzicielstwo jest zakorzenione w biologii, ale równocześnie ją przewyższa. Rodzice są bowiem współpracownikami Boga Stwórcy, a w ludzkim rodzicielstwie Bóg sam jest obecny. Rodzicielstwo jest więc nie tylko

${ }^{55}$ Por. DCE 17.

${ }^{56}$ Benedykt XVI stwierdził, że ,jedynie służba bliźniemu otwiera mi oczy na to, co Bóg czyni dla mnie, i na to jak mnie kocha" (DCE 18).

${ }^{57}$ RF 59; por. Polak, Od teologii do eklezjologii pastoralnej, 73. 
zadaniem natury fizycznej, ale także duchowej ${ }^{58}$, dlatego łączy się z misją. Synod Biskupów (2015) wskazał, że misja ta obejmuje, między innymi, płodne zjednoczenie małżonków i wychowanie dzieci ${ }^{59}$.

Świadectwo rodzicielstwa dotyczy zarówno wielkoduszności wobec Boga w przyjęciu poczętego życia, jak również szacunku i wsparcia udzielanego rozwijającej się i dojrzewającej osobie poprzez wychowanie. To ostatnie stanowi istotną cechę rodziny, w której ma miejsce prorodzinne wychowanie oraz międzypokoleniowy przekaz wartości ${ }^{60}$. List do rodzin zawiera stwierdzenie, że ,człowiek wychodzi z rodziny, aby z kolei w nowej rodzinie urzeczywistnić swe życiowe powołanie" ${ }^{\text {"1 }}$. Na tożsamość rodziny składają się zatem nie tylko pewne wartości, a także prorodzinny charakter wychowania. Rodzina jest zatem powołana do dawania świadectwa swojej tożsamości następnym pokoleniom. Rolę tego świadectwa podkreślił papież Jan Paweł II, stwierdzając, że ,przygotowanie do przyszłego życia małżeńskiego jest przede wszystkim zadaniem rodziny" $"$.

Świadectwo człowieczeństwa rodziców spełnia kluczową rolę w wychowaniu seksualnym dzieci do miłości i czystości. Synod przypomniał, że w rodzinie uczymy się znaczenia cielesności i języka miłości opartego na różnicy między kobietą a mężczyzną oraz współpracy w planie Stwórcy ${ }^{63}$.

${ }^{58}$ LdR 9-10.

${ }^{59}$ Por. RF 89.

${ }^{60}$ Według L. Dyczewskiego (Rodzina - społeczeństwo - państwo, 27), rodzina jest wspólnotą osób i instytucją społeczną opartą na miłości i wolnym wyborze kobiety i mężczyzny połączonych małżeństwem, którzy odpowiadając wzajemnie za siebie, rodzą i wychowują następne pokolenie w taki sposób, aby ono także rodziło i wychowywało nowe pokolenie.

${ }^{61}$ LdR 2.

${ }^{62}$ Papież zaznaczył, że tylko rodziny zdrowe duchowo mogą należycie spełnić to zadanie. LdR 16.

${ }^{63} \mathrm{RF} 16$. Synod jednocześnie podkreśla, że rodzina nie może być jedynym miejscem wychowania do seksualności. Wskazuje, że należy 
Do istotnych elementów świadectwa zalicza się pozytywną obecność matki i ojca oraz akceptację dziecka. Obecność ta wspomaga identyfikację płciową dziecka oraz niesie z sobą modele zachowań matki i ojca, pomocne w przyjęciu własnej tożsamości płciowej oraz podjęciu w przyszłości ról zgodnych z płcią biologiczną.

Ze świadectwem pozytywnej obecności łączy się ściśle tworzenie klimatu miłości w rodzinie. Klimat ten stanowi najważniejszy czynnik wychowawczy w kształtowaniu osobowości i emocjonalności dzieci6 ${ }^{64}$. Zależy on przede wszystkim od relacji małżeńskiej, która konstytuuje rodzinę i wpływa znacząco na jej funkcjonowanie ${ }^{65}$. Klimat miłości w rodzinie obejmuje także wzajemne zaufanie oraz miłość rodziców wobec dzieci. Miłość rodzicielska przejawia się w czułości, stałości, dobroci, usłużności, bezinteresowności i ofiarności ${ }^{66}$. Dzieci, które doświadczają miłości w rodzinie, są lepiej przygotowane do życia według prawd moralnych, którymi żyją ich rodzice. Świadomość dzieci, że są miłowane, budzi ich zaufanie do rodziców oraz w najwyższym stopniu pobudza do miłości ${ }^{67}$. W ten sposób klimat miłości sprzyja nie tylko integracji seksualności z uczuciowością, ale pomaga w dojrzewaniu do miłości. Dzięki miłości rodziców lub ich zastępców oraz nieskończonej miłości Boga, który jest źródłem wszelkiej prawdziwej miłości ${ }^{68}$, dokonuje się uwalnianie dziecka $\mathrm{z}$ tendencji do egoizmu. Klimat miłości w rodzinie pomaga kształtować u dziecka świadomość bycia umiłowanym i obdarowanym przez Boga, co w efekcie wspiera integrację seksualną na poziomie osobowym - ukierunkowuje dziecko na miłość jako dar z siebie dla Boga i bliźniego.

stworzyć właściwe duszpasterskie programy wsparcia ze szczególnym uwzględnieniem wieku dojrzewania i dorastania, w którym trzeba pomóc odkryć piękno seksualności w miłości. Por. RF 58. 239.

${ }^{64}$ LP 50; por. RF 31; Nicola - Danese, Mężczyzna i kobieta, 238-

${ }^{65}$ Zob. Braun-Gałkowska, Psychologiczna analiza, 144-151.

${ }^{66}$ Por. FC 36.

${ }^{67}$ LP 52; zob. FC 18, 63-64.

${ }^{68}$ LP 9; zob. Jan Paweł II, Christifideles laici, 34. 
W ten sposób poprzez miłość wzajemną oraz miłość wobec dzieci rodzice obdarzają je człowieczeństwem i stopniowo rodzą $\mathrm{w}$ wymiarze duchowym ${ }^{69}$.

W wychowaniu szczególnie cenne jest świadectwo dobrego przykładu ${ }^{70}$. Wzór matki i ojca odnoszących się z szacunkiem do swojego powołania macierzyńskiego i ojcowskiego stanowi wsparcie synów i córek w ich rozwoju, ukazuje konkretne wzorce osobowe oraz kształtuje postawy wobec osób płci odmiennej ${ }^{71}$. Dobry przykład rodziców w wychowaniu do miłości ma miejsce tam, gdzie rodzice sami przeżywają wierną i ofiarną miłość, zachowują czystość małżeńską oraz są odpowiedzialni i wielkoduszni w przyjęciu życia ${ }^{72}$. Środowisko takie pozwala dziecku doświadczać akceptacji, nieodwołalnego przyjęcia i zakorzenienia w życiu oraz kształtuje zdolność do działania moralnego i odpowiedzialnego kierowania własnym życiem ${ }^{73}$. Przykład i pomoc rodziców wspomaga zamiłowanie dzieci do czystości i przygotowuje je do odpowiedzialnego ojcostwa i macierzyństwa w przyszłości. Ważne jest także wzajemne poszanowanie intymności i sumienia. Poszanowanie to kształtuje u dziecka podobną postawę wobec innych osób oraz sprzyja kształtowaniu odpowiedzialności przed Bogiem, przed sobą samym i innymi ludźmi. Wiara, głęboka świadomość obdarowania przez Boga oraz Jego łaska pozwalają rodzicom chrześcijańskim wznosić się na wyżyny świadectwa dobrego przykładu ${ }^{74}$.

Cennym świadectwem jest prowadzenie przez rodziców dialogu z dziećmi na przestrzeni czasu. Dialog taki odgrywa ważną rolę w kształtowaniu uczuciowości. Prowadzony od najmłodszych lat buduje zaufanie potrzebne do rozmawiania na tematy osobiste i intymne, zwłaszcza dotyczące tematyki uczuciowej, moralnej i religijnej. Dialog ten jest niezbędny w wychowaniu seksualnym

${ }^{69}$ LdR 16.

${ }^{70}$ WW 50.

${ }^{71}$ Por. LP 59.

72 Por. HV 21; FC 20, 33; LP 20.

${ }^{73}$ Por. Buttiglione, Etyka w kryzysie, 44-46.

${ }^{74}$ LP 31-32, 57, 12. 
i wtajemniczeniu w prokreację, uważa się go za podstawowa metodę uświadamiania i nauczania w tym zakre$\mathrm{sie}^{75}$. Uświadomienie seksualne jest zadaniem rodziców i stanowi uzupełnienie doświadczenia miłości w rodzinie ${ }^{76}$. Synod Biskupów (2015) wiąże to zadanie z przekazywaniem wiary i wskazuje na potrzebę języka, który mógłby dotrzeć do dzieci i młodzieży, a dzięki temu wprowadzić ich w tematykę płciowości, przekazać piękno miłości rodzinnej i pozwolić zrozumieć znaczenie takich pojęć, jak: dar z siebie, miłość małżeńska, wierność, płodność, prokreacja $^{77}$. Rozmowy rodziców z dziećmi dotyczące seksualności i płodności prowadzone w odpowiednim czasie oddziałują profilaktycznie $^{78}$.

Ponieważ wychowanie zmierza do tego, by młody człowiek zaczął wychowywać się sam ${ }^{79}$, w dialogu rodzinnym nie może zabraknąć ukazywania znaczenia wartości moralnych i religijnych, a także czynnika konsekwencji i świadomego dyscyplinowania, pomocnego w samowychowaniu. Na drodze dialogu możliwe jest wówczas wyjaśnianie i pomoc w rozumieniu treści norm i wymagań oraz ukazywanie ich pozytywnej wartości. W prowadzeniu dialogu i stawianiu pewnych wymagań pomaga rodzicom bliska więź uczuciowa z dzieckiem.

Świadectwo dialogu rodziców z dzieckiem jest jedną z najcenniejszych form obdarzania człowieczeństwem, gdyż służy duchowemu rodzeniu człowieka. Synod (2015) zwraca uwagę w tym kontekście na rolę obecności dziadków w rodzinie, jako ogniwa łączącego pokolenia. Zapewniają oni równowagę psychiczno-uczuciową, gdyż przekazują tradycje i zwyczaje, wartości i cnoty, dzięki czemu najmłodsi mogą rozpoznać swoje korzenie ${ }^{80}$.

Najpełniejsze świadectwo w wymiarze ludzkim może zajaśnieć w życiu wierzących w Chrystusa małżonków sa-

${ }^{75}$ Zob. LP 65-76; Joyeux, L'École, 11.

${ }^{76}$ Augustyn, Wychowanie, 46.

${ }^{77}$ RF 56.

${ }^{78}$ LP 59, 66.

${ }^{79}$ LdR 16.

${ }^{80}$ RF 18. 
kramentalnych. Ich świadectwo człowieczeństwa scalone życiem wiarą zostaje przepojone nowym znaczeniem i motywacją, jakie nadaje im sakrament małżeństwa i powołanie małżeńsko-rodzinne. Łaska sakramentu małżeństwa uzdalnia do głębszego odkrycia sensu człowieczeństwa oraz bogatszej jego realizacji.

\section{ROLA ŚWIADECTWA WIARY}

Odsłonięcie się osoby przed osobą obejmuje także wyznawanie wiary w Chrystusa. W rodzinie chrześcijańskiej konkretne i codzienne świadectwo wiary jest cechą typową życia rodzinnego ${ }^{81}$. Sobór Watykański II zachęca do tego świadectwa najpierw małżonków, aby zespoleni wspólną świętością, ,idąc za Chrystusem, zasadą życia, stawali się przez radość i ofiary swego powołania, przez wierną swoją miłość świadkami owego misterium miłości, które Pan objawił światu swą śmiercią i zmartwychwstaniem" (KDK 52). Świadectwo takie toruje drogę wierze i świętości pozostałych członków rodziny. „Dzieci, a nawet wszyscy pozostający w kręgu rodzinnym, znajdą łatwiej drogę szlachetności, zbawienia i świętości, jeżeli torować ją będzie przykład rodziców i modlitwa rodzinna". Sobór dodaje, że także dzieci przyczyniają się na swój sposób do uświęcania rodziny (KDK 48).

Rodzina chrześcijańska jest wpisana w tajemnicę Kościoła i staje się uczestnikiem jego zbawczego posłannictwa, a także symbolem, świadectwem i uczestnikiem jego macierzyństwa ${ }^{82}$. Wpisanie to pozwala odnieść posłannictwo Kościoła domowego do posłannictwa Chrystusa Proroka, Kapłana i Króla. W tym świetle rodzina jest wspólnotą, która wierzy i ewangelizuje, wspólnotą dialogu z Bogiem oraz służby człowiekowi ${ }^{83}$. Wiara w Chrystusa i Jego łaska pozwalają jego wyznawcom tworzyć wspól-

\footnotetext{
${ }^{81}$ Por. Jan Paweł II, Catechesi tradendae, 68 [dalej: CT].

${ }^{82} \mathrm{FC} 49$.

${ }^{83}$ FC 50.
} 
noty religijne - Kościoły domowe. Rodzina, podobnie jak Kościół, jest miejscem głoszenia słowa Bożego, przestrzenią kultu i modlitwy oraz służby miłości drugiemu człowiekowi ${ }^{84}$. Świadectwo wiary w rodzinie obejmuje życie słowem Bożym i jego głoszenie, realizację kapłaństwa chrzcielnego oraz postawę miłości służebnej i zaangażowania w budowanie wspólnoty eklezjalnej.

\section{1. Świadectwo głoszenia słowa Bożego}

Życie słowem Bożym czyni z rodziny wspólnotę wierzącą i pozwala jej świadczyć o tajemnicy swego powołania. Dzięki słowu Bożemu rodzina chrześcijańska odkrywa swoją tożsamość - to, czym jest i powinna być według zamysłu Pana ${ }^{85}$. Słowo Boże potwierdza pierwotną dobroć człowieka, stworzonego jako mężczyzna i kobieta i powołanego do wiernej, wzajemnej i płodnej miłości. Ponadto stanowi ono cenne wsparcie małżonków w trudnościach życia małżeńskiego i rodzinnego. Życie słowem Bożym domaga się, aby w każdej chrześcijańskiej rodzinie była Biblia i aby była czytana z modlitwą ${ }^{86}$.

Rodzina chrześcijańska przyjmująca i głosząca słowo Boże spełnia swoją funkcję prorocką. Zależnie od stopnia przyjęcia Ewangelii i dojrzałości w wierze rodzina staje się wspólnotą ewangelizującą ${ }^{87}$. Sobór Watykański II naucza, że małżonkowie chrześcijańscy na mocy sakramentu małżeństwa wspomagają się wzajemnie w życiu małżeńskim oraz rodzeniu i wychowaniu potomstwa dla zdobycia świętości (KK 11). Według papieża Jana Pawła II rodzina ochrzczonych zgromadzona przez Słowo i Sakrament staje się, podobnie jak wielki Kościół, nauczycielem i matką ${ }^{88}$. Papież Benedykt XVI dostrzegł duchowy związek ojcostwa i macierzyństwa z dawaniem

\footnotetext{
${ }^{84}$ Fiałkowski, ,Rodzina”, 708-709.

85 Benedykt XVI, Verbum Domini, 85 [dalej: VD].

86 Por. VD 85.

87 Por. FC 51-52.

${ }^{88} \mathrm{FC} 38$.
} 
świadectwa słowu Bożemu i wierze w życiu małżeńskim i rodzinnym. Stwierdził, że „do autentycznego ojcostwa i macierzyństwa należy ukazywanie sensu życia w Chrystusie i świadczenie o nim: przez wierność i jedność życia rodzinnego małżonkowie są dla swoich dzieci pierwszymi zwiastunami słowa Bożego"89. Dostrzegamy tutaj głęboki związek ,świadectwa człowieczeństwa” z wiarą, bez której nie może ono osiągnąć swojej pełni. Jednocześnie świadectwo wiary dawane Wcielonemu Słowu przez małżonków i rodziców objawia najgłębszy sens ich powołania. Są oni wzajemnie dla siebie, dla swoich dzieci oraz innych domowników świadkami i głosicielami wiary, którą głoszą słowem i przykładem (por. DA 11, KK 11). Dlatego małżonków nazywa się prorokami wobec siebie wzajemnie oraz swoich dzieci i społeczności, w której żyjąa ${ }^{90}$.

Świadectwo słowa Bożego w rodzinie przybiera także formę katechezy. Rodzice uczą dzieci prawd wiary nie tylko w imieniu własnym, ale także w imieniu Kościoła ${ }^{91}$. Papież Jan Paweł II nazwał rodziców także ,pierwszymi i niezastąpionymi katechetami swoich dzieci" "92. Katecheza rodzinna wyprzedza inne formy katechezy albo im towarzyszy, poszerza je i upraktycznia ${ }^{93}$. Zmierza ona do rozbudzenia i rozwinięcia wiary u dzieci oraz przyjęcia jej za własną. Rodzina zmierza w tym kierunku, gdy czyni życie rodzinne szkołą życia chrześcijańskiego. W rozwijaniu wiary nie wystarczy tylko przekazać pewien zasób wiadomości i reguł postępowania, ale trzeba także uczyć dzieci ich realizacji w codziennym życiu ${ }^{94}$. Ponadto posługa katechetyczna rodziców powinna towarzyszyć dzieciom także w okresie ich dojrzewania i młodości, kiedy kontestują one lub odrzucają wiarę chrześcijańską otrzymaną w pierwszych latach życia. Wówczas rodzice, jako apo-

\footnotetext{
89 VD 85.

90 Por. Wolski, „Funkcja prorocka rodziny”, 293.

91 Fiałkowski, „Rodzina”, 710.

${ }^{92} \mathrm{ChL} 34$.

${ }^{93}$ CT 68.

94 Por. Fiałkowski, „Rodzina”, 710.
} 
stołowie Chrystusa, mają udział w dziele ewangelizacji własnych dzieci poprzez cierpienie ${ }^{95}$.

Katecheza rodzinna przybiera różne formy. Za najważniejszą należy uznać regularne czytanie i rozważanie słowa Bożego ${ }^{96}$. Na katechezę tę składają się także proste gesty religijne, uczenie języka religijnego, pielęgnowanie zwyczajów chrześcijańskich, nauka modlitw i pieśni religijnych oraz zaznajamianie z prawdami wiary. Rodzice zatroskani o katechezę rodzinną starają się wykorzystywać nadarzające się okazje, aby prowadzić z dziećmi rozmowy na tematy religijne, interpretować ważne wydarzenia życiowe w świetle wiary i wyjaśniać wątpliwości. Dzięki temu dzieci odczuwają i przeżywają odkrywane tajemnice. Dobre świadectwo katechezy rodzinnej wymaga przede wszystkim żywej wiary samych rodziców. Trzeba jednocześnie podkreślić, że właśnie szeroki udział świadectwa wiary sprawia, iż formacja dzieci w środowisku rodziny wykazuje dużą skutecznośćc ${ }^{97}$.

Papież Jan Paweł II zauważył, że wiara i posłannictwo ewangelizacyjne rodziny mają charakter misyjny. Sakrament małżeństwa czyni bowiem małżonków i rodziców chrześcijańskich świadkami Chrystusa aż po krańce ziemi (Dz 1,8). Są oni - przede wszystkim - misjonarzami miłości i życia. W pewnej mierze działalność misyjną mogą oni prowadzić już wewnątrz rodziny. Chodzi o sytuacje, gdy któryś z członków rodziny nie wierzy lub nie praktykuje konsekwentnie. „W tym przypadku inni członkowie rodziny winni dać mu żywe świadectwo ich wiary, które by go pobudziło i podtrzymało na drodze ku pełnemu przylgnięciu do Chrystusa Zbawiciela" ${ }^{98}$. Nieocenioną wartość ma świadectwo wiary współmałżonka wówczas, gdy drugi małżonek nie czuje potrzeby rozwijania życia religijnego ${ }^{99}$.

\footnotetext{
${ }^{95}$ FC 53.

${ }^{96}$ Por. Murawski, „Rodzina”, 98-99.

${ }^{97}$ Por. Fiałkowski, „Rodzina”, 710-711.

${ }^{98}$ FC 54.

${ }^{99}$ Por. Zarembski, „Ewangelizacja”, 182.
} 
Głoszenie Chrystusa w Kościele domowym nie ogranicza się jednak tylko do własnej rodziny. Małżonkowie podejmują także apostolat względem innych małżonków, z którymi dzielą się swoimi doświadczeniami ${ }^{100}$. Adhortacja apostolska Familiaris consortio zawiera stwierdzenie, że Chrystus udziela małżonkom specjalnego apostolskiego mandatu i posyła ich na pole życia rodzinnego ${ }^{101}$. Synod Biskupów (2015) przypomniał, że misja rodziny w wymiarze religijnym obejmuje świadectwo sakramentu, przygotowanie innych par do małżeństwa i przyjazne towarzyszenie małżeństwom lub rodzinom napotykającym trudności ${ }^{102}$. Kościół domowy jest powołany także do bycia znakiem obecności Chrystusa i Jego miłości dla ludzi będących daleko od Niego, zwłaszcza dla rodzin jeszcze niewierzących i dla tych, które już nie żyją konsekwentnie wedle otrzymanej wiary. Jest on jest wezwany, aby oświecał swoim przykładem i świadectwem poszukujących prawdy ${ }^{103}$.

\section{2. Świadectwo kaplaństwa chrzcielnego}

Wszyscy wierni uczestniczą w kapłaństwie wspólnym ochrzczonych. Cały Lud Boży, wcielony w Chrystusa przez chrzest i bierzmowanie, stanowi Jego Mistyczne Ciało oraz uczestniczy w godności i funkcji kapłańskiej Jezusa Chrystusa. Kapłaństwo chrzcielne praktykowane jest w szczególny sposób w rodzinie poprzez ,przyjmowanie sakramentów, modlitwę i dziękczynienie, świadectwo życia świątobliwego, zaparcie się siebie i czynną miłość" (KK 10, 11; por. DA 3). Chrystus Pan poprzez sakrament małżeństwa ożywia nieustannie rodzinę chrześcijańską i wzywa ją do dialogu z Bogiem poprzez życie sakramentalne, ofiarę życia i modlitwę. Z sakramentu małżeństwa pochodzi łaska i obowiązek przemiany całego życia mał-

\footnotetext{
100 HV 26.

101 FC 71.

102 RF 89.

103 FC 54.
} 
żonków w nieustanną ,ofiarę duchową" składaną Bogu przez Jezusa Chrystusa (por. 1 P 2,5) - KK 34.

Pełniąc zadanie kapłańskie w komunii z całym Kościołem, małżeństwo i rodzina, poprzez codzienne życie, uświęca siebie, wspólnotę kościelną i świat ${ }^{104}$. Łaska sakramentu małżeństwa nadaje bowiem uświęcającą rangę także zwykłym czynnościom wspólnoty małżeńskiej i rodzinnej. Dlatego domowy Kościół jest ośrodkiem życia religijnego i kultu oddawanego $\mathrm{Bogu}^{105}$. Tym samym może dawać czytelne świadectwo udziału w kapłaństwie Chrystusa.

Pierwszą formą pełnienia funkcji kapłańskiej w rodzinie i świadectwa kapłaństwa chrzcielnego jest uczestnictwo w liturgii Kościoła i przyjmowanie sakramentów. Stanowi ono dla małżonków źródło uświęcenia. Papież Jan Paweł II podkreślił, że uświęcenie małżonków najpełniej dokonuje się w Eucharystii, z którą chrześcijańskie małżeństwo jest wewnętrznie związane. Ta ofiara Nowego i Wiecznego Przymierza odnawia i ożywia przymierze małżonków chrześcijańskich, gdyż jest źródłem miłości ${ }^{106}$. Papież Benedykt XVI dodał, że Eucharystia wzmacnia w sposób niewyczerpany jedność i nierozerwalną miłość każdego chrześcijańskiego małżeństwa ${ }^{107}$. A zatem pełny udział małżonków w Eucharystii jest nie tylko źródłem ich uświęcenia, ale także formą odnowy przymierza małżeńskiego i czerpania ze źródła miłości Chrystusa. Udział małżonków w Eucharystii przynosi wielorakie owoce w ich życiu małżeńskim i rodzinnym. Ożywia komunię małżeństwa i rodziny oraz jest źródłem ich apostolskiego i misyjnego posłannictwa ${ }^{108}$. Pełny udział w Eucharystii jest źródłem chrześcijańskiego świadectwa w rodzinie, a komunia małżonków z Chrystusem jest jego doskonałą formą.

104 FC 55-56.

105 Fiałkowski, ,Rodzina”, 712.

106 FC 57.

107 Benedykt XVI, Sacramentum caritatis, 27.

108 Por. FC 57. 
Zarówno przygotowanie do Eucharystii w rodzinie przeżywane przez małżonków ze świadomością składania na ołtarzu Pańskim duchowej ofiary ze swego życia, jak również wspólne uczestnictwo rodziny w liturgii wprowadza małżonków i dzieci coraz głębiej w życie sakramentalne. Świadectwo głębokiego uczestnictwa w liturgii owocuje szczególnie w wychowaniu religijnym dzieci, gdyż od fundamentów położonych w rodzinie zależy w dużej mierze życie sakramentalne dzieci w ich dorosłym życiu $^{109}$. Synod (2015) zachęcił rodziców, aby jako pierwsi wychowawcy i świadkowie wiary dla swoich dzieci byli zaangażowani w przygotowanie do sakramentów wtajemniczenia chrześcijańskiego ${ }^{110}$.

Przyjęcie przez rodzinę ewangelicznego wezwania do nawrócenia oraz korzystanie z sakramentu pokuty i pojednania jest źródłem uświęcenia oraz czytelnym świadectwem przynależności do Chrystusa. Grzechy nie powinny prowadzić wierzących do upadania na duchu, ale do pokornego i wytrwałego uciekania się do Bożego miłosierdzia. Właśnie dlatego, że grzech sprzeciwia się nie tylko przymierzu z Bogiem, ale także przymierzu małżeńskiemu i komunii rodzinnej, warto $w$ rodzinie dawać sobie nawzajem świadectwo zaufania Miłosiernemu Bogu, który odbudowuje i udoskonala komunię małżeńską i rodzinną ${ }^{111}$. Papież Franciszek podkreślił znaczenie tegoż zaufania, gdy napisał: „Do wszystkich powinna dotrzeć pociecha oraz impuls zbawczej miłości Boga, działającej tajemniczo w każdym człowieku, niezależnie od jego ułomności i upadków"112.

W dawaniu świadectwa kapłaństwa chrzcielnego wiernych znaczącą rolę odgrywa „liturgia domowego Kościoła”, poprzez którą dokonuje się uświęcenie i ewangelizacja rodziny. Pozostaje ona w ścisłym związku z liturgią Kościoła powszechnego. Obydwie wzajemnie się dopełniają,

${ }^{109}$ Por. Fiałkowski, „Rodzina”, 712.

${ }^{110}$ RF 67.

${ }^{111}$ FC 58.

${ }^{112}$ Franciszek, Evangelii gaudium, 44. 
a liturgia sprawowana $\mathrm{w}$ rodzinie winna wypływać i nawiązywać do liturgii Kościoła powszechnego ${ }^{113}$. Z jednej strony podejmowanie posług i funkcji w liturgii celebrowanej we wspólnotach parafialnych jest dla współmałżonka, dzieci, członków rodziny oraz innych osób czytelnym świadectwem chrześcijańskim, z drugiej - świadectwem wiary i umiłowania modlitwy jest także liturgia Kościoła domowego sprawowana przy domowym ołtarzyku lub w oratorium, gdzie rodzina spotyka się na modlitwie oraz rozważaniu i medytacji słowa Bożego ${ }^{114}$. Na liturgię domową składa się także celebrowana w rodzinie Liturgia Godzin, będąca publiczną i wspólną modlitwą Ludu Bożego (KL 90, 98) $)^{115}$. Jej celem jest uświęcenie dnia i ludzkiej działalności oraz przygotowanie modlących się do owocnego przeżywania Eucharystii. Ożywia ona wiarę, nadzieję i miłość oraz pobożność i ducha ofiary. Zalecane jest włączenie się rodziny w odmawianie jakiejś jej części, np. jutrzni i nieszporów ${ }^{116}$. Liturgii Godzin celebrowanej w domu przewodniczy ojciec lub matka ${ }^{117}$.

Na liturgię domową składają się także błogosławieństwa Kościoła, których szafarzami mogą być ludzie świeccy. Są one wyrazem troski Kościoła, aby małżonkowie i inni członkowie rodziny stawali się zdolni do wypełniania swoich zadań. Zwłaszcza udzielanie błogosławieństw przez rodziców jest ich własnym uprawnieniem wynikającym z kapłaństwa chrzcielnego ${ }^{118}$. W rodzinie szczególne znaczenie mają błogosławieństwa dzieci, błogosławieństwa związane $\mathrm{z}$ obchodami roku liturgicznego i kultem świętych oraz błogosławieństwa przy rodzinnym stole. Ukazują one łączność codziennego życia chrześcijanina z liturgią oraz owocują łącznością wzajemną. W liturgię Kościoła domowego włącza się także pielęgnowanie zwyczajów obchodzenia okresów liturgicznych roku kościelne-

${ }^{113}$ FC 61; por. Fiałkowski, „Rodzina”, 712.

${ }^{114}$ Por. KKK 2691.

115 Ogólne wprowadzenie do Liturgii Godzin 1 [dalej: OWLG].

116 Por. OWLG 27.

${ }^{117}$ Por. Krakowiak, „Funkcja kapłańska rodziny”, 257.

${ }^{118}$ Obrzędy błogosławieństw, 16-17, 41, 58. 
go, świąt kościelnych, rocznic oraz własnych uroczystości rodzinnych, np. jubileuszy, dni urodzin i imienin, rocznic śmierci. Przejawem świętowania rodziny jest także zasiadanie jej członków do wspólnego stołu ${ }^{119}$. Celebrowanie liturgii Kościoła domowego, a zwłaszcza Liturgii Godzin i obrzędów błogosławieństw w rodzinie nie tylko owocuje we właściwy im sposób per se, ale jest także świadectwem wiary. Pozostawia ono w życiu członków rodziny niezatarte przeżycia religijne, umacnia komunię małżeńską i wspólnotę rodzinną.

Swiadectwo kapłaństwa chrzcielnego wyraża się także w modlitwie rodziny. Małżonkowie powinni być wobec siebie nawzajem i wobec swoich dzieci nauczycielami i świadkami modlitwy ${ }^{120}$. Modlitwa małżonków z dziećmi jest owocem i wymogiem komunii otrzymanej w sakramentach chrztu i małżeństwa ${ }^{121}$. Wspólna modlitwa umacnia jedność rodziny. „Rodzina, która modli się zjednoczona, zjednoczona pozostaje"122. Każda rodzina powinna włączać swoje codzienne życie w modlitwę i wypracowywać własny styl modlitwy. Kościół zaleca modlitwę wspólną, łączącą małżonków i dzieci (DA 11) ${ }^{123}$.

Świadectwo modlitwy osobistej, małżeńskiej i rodzinnej przyczynia się do podtrzymywania ducha modlitwy w rodzinie, stopniowo wprowadza dzieci w Boże misterium oraz uczy osobistej rozmowy z Bogiem, a ponadto motywuje do modlitwy. Papież Jan Paweł II stwierdził, że żywe świadectwo ojca i matki modlących się wspólnie z dziećmi sprawia, iż ,zstępują w głąb serc dzieci pozostawiając ślady, których nie zdołają zatrzeć późniejsze wydarzenia życiowe”. Przykład życia rodziców poparty modlitwą stanowi zasługujący akt kultu, wnosi w progi domu pokój i jest budowaniem Kościoła. Zwłaszcza pobożność maryjna związana z modlitwą różańcową jest

${ }^{119}$ Fiałkowski, ,Rodzina”, 713-714.
${ }^{120}$ Por. Kobak, ,Rodzina”, 186.
${ }^{121}$ FC 59.
${ }^{122}$ Jan Paweł II, List o Różańcu, 41.
${ }^{123}$ Paweł VI, Marialis cultus, 25; FC 59. 
„uprzywilejowanym środkiem zasilania komunii miłości w rodzinie i rozwijania duchowości małżeńskiej i rodzinnej"124.

Modlitwa jest także podstawą przekazu wiary szerszemu otoczeniu. Jest ona ważna szczególnie w działalności apostolskiej oraz duszpasterstwie małżeństw i rodzin ${ }^{125}$. Rodzina odkrywająca swoje powołanie do apostolatu i ewangelizacji otoczenia odkrywa także zaproszenie do rozwijania daru modlitwy oraz formacji osób i wspólnot do modlitwy. Służy temu apostolat modlitwy we wspólnocie Kościoła oraz środowisku społecznym ${ }^{126}$.

\section{3. Świadectwo milości służebnej i apostolatu}

Świadectwo chrześcijańskie w rodzinie można widzieć także jako realizację funkcji królewskiej (pasterskiej), polegającej na życiu nowym przykazaniem miłości, którego najdoskonalszy wzór dał sam Chrystus (por. J 13,1-11). Według adhortacji apostolskiej Familiaris consortio przewodnikiem małżonków i rodziców jest Duch Jezusa, rozlany w sercach przez sakrament małżeństwa, który stawia przed małżonkami chrześcijańskimi prawo ewangelicznej miłości. Rodzina chrześcijańska jest wezwana do służby miłości wobec Boga i wobec braci ${ }^{127}$. Udział rodziny w tej funkcji Chrystusa polega na posiadaniu Jego królewskiej wolności - zdolności do zaparcia się siebie i pokonywania grzechu w sobie samym oraz służby Chrystusowi w bliźnich. Pan pragnie, aby wierni świeccy swoją pokorą i cierpliwością przywodzili braci do Króla i jego królestwa prawdy i życia, świętości i łaski, sprawiedliwości, miłości i pokoju (por. KK 36).

Służba innym na wzór Jezusa Chrystusa - Sługi nikogo nie pomniejsza, ale nobilituje i pozwala na urzeczywistnianie dojrzałego człowieczeństwa oraz przyczynia się do

${ }^{124}$ Por. FC 60-61; RF 60.

${ }^{125}$ Benedykt XVI, „Rodzina chrześcijańska”; por. LdR 14.

${ }^{126}$ Kobak, „Rodzina”, 186.

${ }^{127} \mathrm{FC} 63$. 
budowania Kościoła jako wspólnoty braterskiej ${ }^{128}$. Służba Chrystusowi w rodzinie i poprzez rodzinę przejawia się przede wszystkim w miłości braterskiej w codziennym życiu, zwłaszcza we wzajemnej pomocy i służbie małżonków, w wychowaniu dzieci do miłości bliźniego oraz zaangażowaniu apostolskim ${ }^{129}$.

Miłość małżeńska i rodzinna czerpie swój ideał oraz motywację od Chrystusa miłującego do końca (por. J 13,1). Czerpie także ożywcze siły z łaski sakramentalnej. Jednocześnie domaga się ona (wspomnianego wyżej) zaangażowania osobistego $\mathrm{w}$ dojrzewanie miłości jako daru $\mathrm{z}$ siebie. Bez zapierania się siebie, wyrzekania się egoizmu i grzechu, będzie mało czytelna lub może pozostać tylko życzeniem.

Rodzina jest powołana do dawania świadectwa miłości Chrystusowej. Papież Jan Paweł II stwierdził, że misją rodziny jest strzeżenie, objawianie i przekazywanie miłości Bożej ludzkości oraz miłości Chrystusa Pana Kościołowi. Rodzina chrześcijańska „żyje gościnnością, szacunkiem i służbą każdemu człowiekowi, w którym zawsze dostrzega godność osoby i dziecka Bożego" 130 . Jej zadaniem jest bycie środowiskiem dobra, życzliwości i miłości. W takiej rodzinie każdy spotyka się z akceptacją, szacunkiem i czcią, ponieważ jest osobą. Jeżeli zaś ktoś bardziej potrzebuje pomocy, zostaje otoczony tym czujniejszą i troskliwszą opieką ${ }^{131}$. Świadectwo miłości w rodzinie wyraża się także w kształtowaniu i pielęgnowaniu postawy miłości jej członków poprzez wzajemną cierpliwość względem siebie, ducha służby i troskę ${ }^{132}$. Przez to świadectwo rodzina uczy miłości. Kongregacja Nauki Wiary stwierdza, że członkowie rodziny ,uczą się kochać na tyle, na ile są bezinteresownie kochani; uczą się szanować każdą inną osobę na tyle, na ile sami są

128 Przygoda, „Funkcja królewska rodziny”, 282.

${ }^{129}$ Fiałkowski, „Rodzina”, 715; por. Przygoda, „Funkcja królewska rodziny", 281.

130 FC 17, 64.

131 Jan Paweł II, Evangelium vitae, 92 [dalej: EV].

132 Por. Fiałkowski, „Rodzina”, 715. 
szanowani, uczą się poznawać oblicze Boga na tyle, na ile pierwsze Jego objawienie otrzymają od matki i ojca zatroskanych o swe potomstwo"133.

Rodzina ożywiona duchem miłości promieniuje przykładem swojego życia także na zewnątrz, stając się dla innych impulsem do życia według Bożych przykazań. Wówczas jest ona w stanie przemieniać swoje środowisko, wychodząc naprzeciw żywotnym potrzebom bliźnich $^{134}$. Miłość chrześcijańska sięga bowiem dalej aniżeli do własnych braci oraz sióstr w wierze i każe we wszystkich, a zwłaszcza w najuboższych, słabych, cierpiących i poniżonych, widzieć oblicze Chrystusa i dostrzegać bliźniego ${ }^{135}$. Wyraźnym świadectwem miłości służebnej jest zaangażowanie rodziny w działalność charytatywną. Adresatem tej posługi sa rodziny i osoby potrzebujące pomocy i podtrzymania. Swiadectwo czynów miłości duchowej i materialnej staje się dla członków rodziny szkołą takiej działalności, która skutecznie jej uczy i w nią wprowadza $^{136}$.

Dawanie świadectwa miłości Chrystusowej w rodzinie wyraża się także w służbie życiu ${ }^{137}$. Jako Kościół domowy jest ona powołana do głoszenia, wysławiania i służenia Ewangelii życia. Małżonkowie są wezwani do przyjmowania z szacunkiem i wdzięcznością daru życia ludzkiego, aby go ponownie ofiarować. Spełniają oni Ewangelię życia przede wszystkim poprzez wychowanie dzieci do właściwego korzystania z wolności. W tym celu słowem i przykładem mają oni uczyć dzieci przyjmowania życia jako daru, a także uczyć bezinteresownego daru z siebie, szacunku dla innych, sprawiedliwości, serdeczności, dialo-

${ }^{133}$ Kongregacja Nauki Wiary, List o współdziałaniu mężczyzny i kobiety, 13.

${ }^{134}$ Por. Kongregacja Nauki Wiary, List o współdziałaniu mężczyzny i kobiety, 13.

${ }^{135}$ FC 64; Fiałkowski, Formacja, 199-200.

${ }^{136}$ Por. FC 71; zob. Przygoda, Postuga charytatywna, 188-196.

137 Według papieża Jana Pawła II obrona i promocja życia ludzkiego jest przejawem uczestnictwa w misji królewskiej Chrystusa. Zob. EV 87. 
gu i wielkodusznej służby. Świadectwo rodziców powinno także pomóc dzieciom pojąć sens cierpienia i śmierci. Służy temu dostrzeganie przejawów cierpienia wokół siebie oraz okazywania serdeczności, opiekuńczości i współczucia chorym i starszym w rodzinie. Wymownym świadectwem miłości służebnej i szacunku dla życia ludzkiego w rodzinie jest także adopcja lub wzięcie pod opiekę dzieci porzuconych lub żyjących w trudnych warunkach ${ }^{138}$.

Poprzez świadectwo miłości chrześcijańskiej rodzina spełnia swoje zadania apostolskie i misyjne. Świadectwo to realizuje się przede wszystkim wewnątrz rodziny i dla jej dobra. Dążenie małżonków do świętości oraz wewnętrzna komunia miłości małżonków zasilana miłością Boga umożliwia tworzenie autentycznej wspólnoty osób - Kościoła domowego. Ponadto rodzina jest źródłem światła i zdrowym zaczynem dla innych rodzin, gdyż ukazuje Kościołowi i światu komunię miłości ${ }^{139}$, będącą darem łaski Chrystusowej. Dzięki chrześcijańskim rodzinom cały Kościół może stawać się bardziej rodzinny ${ }^{140}$. Papież Benedykt XVI podkreślił misyjny charakter świadectwa rodziny posłusznej Bogu: „Gdy rodzina chrześcijańska pokłada ufność w Bogu i jest Mu posłuszna, dochowuje $\mathrm{Mu}$ wierności i wielkodusznie przyjmuje dzieci, troszczy się o najsłabszych, jest gotowa przebaczać, wówczas staje się żywą Ewangelią, którą wszyscy mogą czytać (por. 2 Kor 3,2), wiarygodnym znakiem, być może bardziej przekonującym i zdolnym przemówić do współczesnego świata" 141 . Synod Biskupów (2015) stwierdza, że misja rodziny jest misją Kościoła i zawsze wykracza poza nią samą (rodzinę) w służbie braciom i siostrom ${ }^{142}$.

Małżonkowie angażują się w budowanie wspólnoty eklezjalnej poprzez apostolat na rzecz narzeczonych i młodych małżonków, dając świadectwo komunii miło-

138 Por. EV 92-93.

139 Synod (2015) zwraca uwagę, że sam fakt przeżywania komunii rodzinnej jest pierwszą formą jej przepowiadania. RF 93.

140 Por. FC 19, 64, 72.

141 Benedykt XVI, ,Rodzina szkołą”.

142 RF 56. 
ści, służby życiu i godzenia intymności życia domowego z wielkodusznym budowaniem Kościoła i społeczeństwa. Rodziny wnoszą swój wkład w dzieło misyjne Kościoła, gdy poprzez wychowanie pomagają dzieciom poznawać miłość Boga ku ludziom oraz pielęgnują ich powołania misyjne. Świadczą one o rozkwicie Kościoła, gdy udają się na tereny misyjne, aby głosić Ewangelię i służyć człowiekowi z miłością Jezusa Chrystusa ${ }^{143}$. Rodzina świadcząca miłość Chrystusa może być skutecznym podmiotem działań misyjnych także tam, gdzie pojawia się obojętność religijna i zanik wiary ${ }^{144}$.

Synod (2015) wyraził radość Kościoła i podziękowanie rodzinom wiernym nauce Ewangelii za świadectwo, jakie dają. Zachęcił je także do dalszego świadectwa, które uwiarygadnia piękno małżeństwa i pozwala doświadczać komunii między osobami odzwierciedlającej misterium miłości Trójcy Swiętej ${ }^{145}$.

\section{Podsumowanie}

Próba ukazania roli świadectwa $\mathrm{w}$ rodzinie $\mathrm{w}$ dwóch wymiarach miała na celu pełniejsze ujęcie zagadnienia, choć w rzeczywistości obydwa wymiary świadectwa przenikają się wzajemnie i uzupełniają. Wymiar ludzki stanowi jego fundament i „materię", a niedobory w tym obszarze mogą znacząco ograniczać i fałszować świadectwo religijne. Świadectwo dawane Chrystusowi w rodzinie chrześcijańskiej, opartej na sakramencie małżeństwa, przybiera czytelną formę wtedy, gdy harmonizuje z dojrzałym i odpowiedzialnym przyjęciem daru człowieczeństwa i seksualności oraz realizacją powołania do miłości. Wiara pozwala pełniej odkrywać te dary, ich wartość i znaczenie oraz uzdalnia do pełniejszego świadectwa życia małżeńsko-rodzinnego. Istotnie pomaga małżonkom łaska

\footnotetext{
${ }^{143}$ FC 54, 69.

${ }^{144}$ Zarembski, „Ewangelizacja”, 187-188.

${ }^{145}$ RF 51.
} 
sakramentów chrztu, bierzmowania, Eucharystii, pokuty oraz małżeństwa. Ich świadectwo doskonali się i owocuje bardziej dzięki modlitwie. Duch Święty uzdalnia i wspiera małżonków i członków rodziny do świadectwa wiary poprzez realizację powołania małżeńsko-rodzinnego w Kościele i świecie.

\section{Bibliografia}

Augustyn J., Wychowanie do integracji seksualnej (Kraków 1994).

Benedykt XVI, „Ewangelizacja i rodzina są nieodłączne. Przemówienie do uczestników XX Zgromadzenia plenarnego Papieskiej Rady ds. Rodziny" (11.12.2011), L'Osservatore Romano 33/2 (2012) 30-31.

Benedykt XVI, „Rodzina chrześcijańska wspólnotą wychowania i wiary. Przemówienie do uczestników Kongresu Diecezji Rzymskiej” (6.06.2005), L'Osservatore Romano 26/9 (2005) 30-33.

Benedykt XVI, „Rodzina szkołą wartości ludzkich i chrześcijańskich. Przesłanie do uczestników spotkania rodzin w Meksyku" (17.01.2009), L'Osservatore Romano 30/3 (2009) 22-24. Benedykt XVI, Adhortacja apostolska o Słowie Bożym w życiu i misji Kościoła Verbum Domini (2010) (=VD).

Benedykt XVI, Encyklika o miłości chrześcijańskiej Deus caritas est (2005) (= DCE).

Benedykt XVI, Posynodalna adhortacja apostolska Sacramentum caritatis (2007).

Braun-Gałkowska M., Psychologiczna analiza systemów rodzinnych osób zadowolonych i niezadowolonych z matżeństwa (Lublin 1992).

Buttiglione R., Etyka w kryzysie (Lublin 1994).

Dyczewski L., Rodzina - społeczeństwo - państwo (Lublin 1994).

Fiałkowski M., „Rodzina jako Kościół domowy”, Duszpasterstwo rodzin. Refleksja naukowa i działalność pastoralna (red. R. Kamiński - G. Pyźlak - J. Goleń) (Lublin 2013) 703-717. 
Fiałkowski M., Formacja chrześcijańska katolików świeckich $w$ świetle nauczania Kościoła wspótczesnego. Studium teologiczno-pastoralne (Lublin 2010).

Franciszek, „Kreatywność i śmiałość. Audiencja generalna” (15.04.2015), L'Osservatore Romano 36/5 (2015) 45-46.

Franciszek, „Od początku stworzenia Bóg błogosławi ludzką miłość. Homilia podczas Mszy św. na rozpoczęcie Synodu" (4.10.2015), L'Osservatore Romano 36/10 (2015) 15-17.

Franciszek, Adhortacja apostolska Evangelii gaudium (2013).

Jan Paweł II, „Co jest prawdziwym dobrem człowieka? Audiencja Generalna" (22.08.1984), Katechezy Ojca Świętego Jana Pawła II. Teologia małżeństwa (red. W. Zega) (Kraków 1999) 405-408.

Jan Paweł II, „Głoście światu „dobrą Nowinę” o czystości serca i przekazujcie orędzie cywilizacji miłości. Homilia wygłoszona podczas Mszy św. w Sandomierzu (12.06.1999)", Zwiastowanie. Pismo Diecezji Rzeszowskiej 8 (1999) 109-114.

Jan Paweł II, Adhortacja apostolska Catechesi tradendae (1979) (= CT).

Jan Paweł II, Adhortacja apostolska Christifideles laici (1988). Jan Paweł II, Adhortacja apostolska Familiaris consortio (1981). Jan Paweł II, Encyklika Evangelium vitae (1995).

Jan Paweł II, List apostolski Mulieris dignitatem (1988) (= MD). Jan Paweł II, List apostolski o Różańcu świętym Rosarium Virginis Mariae (2002).

Jan Paweł II, List do rodzin Gratissimam sane (1994).

Jaworski P., „Prorok jako świadek (Jr 23,16-22)”, Verbum Vitae 27 (2015) 77-94.

Joyeux H., L'École de la vie et de l'amour. Le livre des parents pour apprendre l'écologie sexuelle de 4 à 20 ans (Paris 1998). Katechizm Kościoła Katolickiego (1992) (Poznań 1994) (=KKK).

Kobak J., „Rodzina szkołą modlitwy”, Roczniki Pastoralno-Katechetyczne 60/5 (2013) 185-199.

Kodeks Prawa Kanonicznego (1983) (Poznań - Warszawa 1984) $(=\mathrm{KPK})$.

Kongregacja Nauki Wiary, List do Biskupów Kościoła katolickiego o współdziałaniu mężczyzny i kobiety w Kościele i świecie (2004). 
Kongregacja Wychowania Katolickiego, Wytyczne wychowawcze w odniesieniu do ludzkiej miłości. Zasadnicze cechy wychowania seksualnego (1983) (= WW).

Krakowiak Cz., „Funkcja kapłańska rodziny - liturgia domowa", Rodzina jako Kościót domowy (red. A. Tomkiewicz - W. Wieczorek) (Lublin 2010) 245-264.

Mastej J., „Świadectwo w argumentacji za wiarygodnością chrześcijaństwa", Verbum Vitae 27 (2015) 227-249.

McCarthy M.H., „Miłość oblubieńcza w świetle «doświadczenia elementarnego»", Miłować ludzka miłość. Dziedzictwo myśli Jana Pawła II o małżeństwie i rodzinie (red. L. Melina - S. Grygiel) (Warszawa 2010) 128-147.

Merecki J., „Ciało jako sakrament osoby”, Miłować ludzka miłość. Dziedzictwo myśli Jana Pawła II o małżeństwie i rodzinie (red. L. Melina - S. Grygiel) (Warszawa 2010) 171-184.

Murawski Cz., ,Rodzina domowym Kościołem”, Program duszpasterski 1993/94, 91-104.

Nicola G.P. di - Danese A., Mężczyzna i kobieta z perspektywy personalizmu (Lublin 2010).

Obrzędy błogosławieństw dostosowane do zwyczajów diecezji polskich (Katowice 1994) I-II.

Ogólne wprowadzenie do Liturgii Godzin (Poznań 1992) (= OWLG).

Papieska Rada do spraw Rodziny, Ludzka płciowość: prawda i znaczenie. Wskazania dla wychowania $w$ rodzinie (1995) $(=\mathrm{LP})$.

Paweł VI, Adhortacja apostolska Marialis cultus (1974).

Paweł VI, Encyklika Humanae vitae (1968) (= HV).

Polak M., Od teologii do eklezjologii pastoralnej. Zagadnienia fundamentalne (Poznań 2014).

Przygoda W., ,Funkcja królewska rodziny - apostolat w rodzinie i przez rodzinę", Rodzina jako Kościót domowy (red.

A. Tomkiewicz - W. Wieczorek) (Lublin 2010) 281-292.

Przygoda W., Postuga charytatywna Kościoła w Polsce. Studium teologicznopastoralne (Lublin 2004).

Relazione finale del Sinodo dei Vescovi al Santo Padre Francesco (24.10.2015) (= RF)

Semen Y., Seksualność według Jana Pawła II (Poznań 2008). 
Sobór Watykański II, Deklaracja o wychowaniu chrześcijańskim Gravissimum educationis (= DWCh).

Sobór Watykański II, Dekret o apostolstwie świeckich Apostolicam actuositatem (= DA).

Sobór Watykański II, Konstytucja dogmatyczna o Kościele $\mathrm{Lu}$ men gentium (= KK).

Sobór Watykański II, Konstytucja duszpasterska o Kościele w świecie współczesnym Gaudium et spes (= KDK).

Sobór Watykański II, Konstytucja o liturgii świętej Sacrosanctum Concilium (= KL).

II Polski Synod Plenarny, „Powołanie do życia w małżeństwie i rodzinie", II Polski Synod Plenarny (1991-1999) (Poznań 2001) 29-48.

Wieczorek W., „Życie duchowe małżeństwa i rodziny”, Duszpasterstwo rodzin. Refleksja naukowa i działalność pastoralna (red. R. Kamiński - G. Pyźlak - J. Goleń) (Lublin 2013) 106-121.

Wolski K., „Funkcja prorocka rodziny - katecheza w rodzinie", Rodzina jako Kościół domowy (red. A. Tomkiewicz - W. Wieczorek) (Lublin 2010) 293-304.

Zarembski Z., „Ewangelizacja w rodzinie przez świadectwo życia chrześcijańskiego", Świadectwo w stużbie ewangelizacji (red. W. Przygoda) (Lublin 2012) 165-189.

Ks. Jacek Goleń

ul. Radziszewskiego 7

20-039 Lublin

jacgolen@gmail.com

Ks. JACEK Goleń, kapłan diecezji rzeszowskiej, doktor habilitowany teologii, kierownik Katedry Duszpasterstwa Rodzin KUL, autor książek: Wychowanie seksualne w rodzinie. Studium pastoralne (Rzeszów 2006); Motywy zawarcia małzeństwa sakramentalnego. Studium z duszpasterstwa rodzin w świetle badań narzeczonych (Lublin 2013). Współredaktor pracy zbiorowej: Duszpasterstwo rodzin. Refleksja naukowa i działalność pastoralna (Lublin 2013). 